\title{
Meningkatkan penerapan SAK EMKM dengan persepsi usaha dan kesiapan pelaku UMKM
}

\author{
Asri Purnomo \\ Program Sarjana Akuntansi, Fakultas Bisnis, Universitas PGRI Yogyakarta \\ asripurnomo112@gmail.com \\ Rahandhika Ivan Adyaksana \\ Program Sarjana Akuntansi, Fakultas Bisnis, Universitas PGRI Yogyakarta \\ rahandhika@upy.ac.id
}

\begin{abstract}
UMKM (Micro Small Medium Enterprises) plays an important role in developed countries, especially in Indonesia, which absorbs a lot of labor to reduce unemployment. This research aims to examine the effect on the application of accounting recording systems, accounting comprehensions, business perceptions, and UMKM preparedness in implementing SAK EMKM. The objects of the research are UMKM in Yogyakarta. The respondents were 120 UMKM owners. This study is using a multiple regression analysis to examine the hypothesis. The research method uses purposive sampling under the criteria in UU No. 20 Tahun 2008 about UMKM Criteria. The result indicates that the hypothesis of the accounting recording system and comprehensions does not affect the implementation of SAK EMKM. Meanwhile, the hypothesis of business perceptions and UMKM preparedness has significant positive effect on the implementation of SAK EMKM.
\end{abstract}

Keywords: Application of Recording System; Accounting Comprehensions; Business Perceptions; UMKM Preparedness; Implementation of SAK EMKM.

\section{Pendahuluan}

Usaha mikro, kecil dan menengah (UMKM) menggenggam peran penting dalam perekonomian di Indonesia yang merupakan negara berkembang, sehingga mendorong laju pertumbuhan ekonomi dan pembangunan menuju arah positive (Budiarto \& Pramudiati, 2018). UMKM mengalami beberapa tantangan dan faktor penentu logistik di bandingkan dengan perusahaan besar, karena alokasi anggaran yang rendah dan personal yang kecil (ALShboul, 2018). Pemerintah harus memperhatikan perkembangan dan keberlangsungan hidup UMKM yang cenderung beroperasi di lingkungan yang kompleks, bergerak cepat, dan tidak dapat diprediksi (Ivers et al., 2016). UMKM berperan sebagai upaya penanggulangan kemiskinan, membuka lapangan kerja, mensejahterakan masyarakat, sarana pemerataan pembangunan dalam mengatasi kesenjangan pendapatan masyarakat antar wilayah pedesaan dan perkotaan yang akan mengurangi arus urbanisasi (Divianto, 2017; Supriadi, 2018). Melihat peran UMKM yang besar bagi Indonesia, UMKM perlu menerapkan pencatatan akuntansi yang baik dan benar, karena tidak semua UMKM menerapkan sesuai dengan SAK, bahkan beberapa UMKM sama sekali tidak menerapkan pencatatan akuntansi karena banyak anggapan bahwa usahanya masih kecil (Pardita, 2019)

Banyak sistem pencatatan keuangan masih menggunakan cara sederhana karena kurangnya pengetahuan pengusaha terhadap tujuan, manfaat dan tahap penyusunan keuangan bebasis SAK EMKM (Wirjono \& Raharjono, 2012). Faktor kegagalan penerapan 
SAK EMKM karena dua faktor, yaitu faktor internal berupa kurangnya sumber daya manusia (SDM) yang kurang mengerti tentang akuntansi dan faktor eksternal kurangnya pengawasan pemangku kepentingan atau stakeholder (Lestari \& Rustiana, 2019). Peranan pencatatan akuntansi antara lain untuk menyediakan laporan keuangan sesuai standar, laporan tersebut berguna sebagai tolak ukur dalam memberikan informasi posisi keuangan, analisis kinerja, dan arus kas (Savitri \& Siafudin, 2018).

Beberapa pelaku usaha berpendapat berbeda tentang persepsi dalam penggunaan SAK ETAP (Kusuma \& Lutfiany, 2018). Persepsi sangat berpengaruh dalam SAK ETAP karena beberapa orang beranggapan bahwa penyajian laporan keuangan hanya mempersulit kinerja, dan tanpa membuat laporan keuangan akan tetap berjalan sewajarnya (Nurfadilah et al., 2019). Pelaku usaha UMKM seharusnya memegang tentang pemahaman akuntansi, akan tetapi kebanyakan berpendapat bahwa hanya seorang manajer dan para pemangku kepentingan saja yang harus memahami (Suparti \& Restuningdiah, 2018). Seseorang yang paham akuntansi itu bisa memahamai jalannya prosedur akuntansi kemudian diaplikasikan menjadi laporan keuangan yang berpedoman pada standar penyusunan laporan keuangan yang berlaku (Harini et al., 2019). Adanya tingkat pemahaman akuntansi menghasilkan laporan keuangan yang berkualitas, sedangkan buruknya penyajian laporan keuangan menimbulkan para pemangku kepentingan memperoleh informasi yang menyesatkan, menyebabkan kesalahan dalam pengambilan keputusan (Puspita \& Promono, 2019; Yenni, 2017).

Praktek kesiapan akuntansi keuangan di UMKM begitu rendah dan masih banyak kekurangan dalam masalah pendanaan baik dengan pihak Bank atau Lembaga Keuangan lainnya (Rahmawati \& Puspasari, 2017). Hal pertama Bank biasanya akan memperhitungkan kelayakan laporan posisi keuangan untuk menilai apakah pantas dalam pengajuan kredit dari UMKM (Masdupi et al., 2019). SAK EMKM tentu mempunyai tujuan dalam menjunjung pengembangan UMKM di Indonesia, oleh sebab itu SAK EMKM harus diterapkan secara optimal (Sholikin \& Setiawan, 2018).

Berdasarkan hal tersebut penelitian ini menarik karena: 1) pelaku UMKM beranggapan pencatatan akuntansi sangat rumit dan merepotkan pekerjaan, jika pencatatan dilakukan oleh seorang ahli dibidangnya maka akan menimbulkan penambahan beban gaji karyawan (Savitri \& Siafudin, 2018); 2) belum adanya minat kesiapan para pelaku usaha dalam memahami SAK EMKM karena hanya akan membuang waktu, dan bisa digunakan untuk pekerjaan lain (Dewi \& Sari, 2019); 3) mayoritas UMKM sekedar membukukan catatan jumlah uang yang diterima, modal yang dikeluarkan, jumlah barang yang dibeli, dan jumlah piutang/utang usaha (Ramdani et al., 2018).

Perbedaan penelitian ini dari penelitian sebelumnya adalah yang pertama penambahan variabel persepsi pengusaha, karena terdapat sejumlah hasil penelitian terdahulu yang tidak konsisten. Penelitian Janros (2018); Salmiah et al. (2019) menunjukan bahwa persepsi pelaku UMKM tidak berpengaruh terhadap penggunaan SAK EMKM. Namun, penelitian Badria (2018); Trisomantagani et al. (2017) menunjukkan bahwa persepsi pelaku UMKM berpengaruh signifikan terhadap penggunaan SAK ETAP. 


\section{Telaah Literatur dan Pengembangan Hipotesis}

\subsection{Sistem Pencatatan Akuntansi}

Sistem pencatatan akuntansi adalah suatu proses untuk mencatat dan menyajikan informasi dan kondisi keuangan yang digunakan untuk membuat keputusan. Sistem pencatatan akuntansi yang diterapkan oleh masing-masing jenis usaha dapat berbeda-beda tergantung dari ukuran usahanya. Semakin besar ukuran usaha maka semakin kompleks sistem pencatatan akuntansi yang diperlukan. Kompleksitas sistem pencatatan akuntansi yang dirancang disebabkan oleh perbedaan kebutuhan informasi untuk masing-masing pembuat keputusan yang ada di dalam usaha tersebut. Sistem pencatatan akuntansi bertujuan untuk mencatat transaksi yang terjadi dan melaporakan hasilnya.

Sistem pencatatan akuntansi dibutuhkan oleh seluruh pelaku dalam dunia usaha termasuk UMKM. UMKM harus memiliki sistem pencatatan akuntansi yang baik untuk memudahkan pemilik dalam menjalankan kegiatan pengendalian alur proses bisnis yang sedang dijalankan, meskipun sistem tersebut masih sederhana (Savitri \& Siafudin, 2018). Sistem pencatatan akuntansi yang sederhana berisi rincian aliran keluar dan masuk pendapatan yang diperoleh melalui aktivitas bisnis, sehingga dapat menyajikan informasi bagi pemilik UMKM dan pihak eksternal atau pemangku kepentingan (Purwanti, 2012; Yusup, 2017).

\subsection{Pemahaman Akuntansi}

Pengetahuan akuntansi merupakan persepsi yang dipandang sebagai fakta, kebenaran atau kewajiban atas informasi yang didalamnya mencakup proses pencatatan, pengolongan mengihktisaran kejadian-kejadian ekonomi yang disusun secara logis dan teratur (Setyawati \& Hermawan, 2018). American Accounting Association menggambarkan akuntansi sebagai "suatu proses pengidentifikasikan, mengukur dan melaporkan informasi ekonomi, untuk memungkinkan adanya penelitian dan keputusan yang jelas dan tegas bagi mereka yang menggunakan informasi tersebut".

Pemahaman akuntansi sangat diperlukan oleh Usaha Mikro Kecil dan Menengah (UMKM) karena penerapan akuntansi akan mengubah posisi keuangan menjadi informasi penting seperti untuk pengambilan investasi akan kredit pada bisnis usaha tersebut (Harryoga, 2015; Mulyadi \& Rozak, 2019). Laporan keuangan menjadikan pemilik memperoleh data informasi tersusun sistematis yang mudah untuk memantau kinerja keuangan, informasi yang berguna bagi keputusan bisnis, memberikan gambaran posisi keuangan dan mempermudah perhitungan pajak (Anisykurlillah \& Rezqika, 2019; Lestari, 2019).

\subsection{Standar Akuntansi Keuangan}

Standar akuntansi keuangan (SAK) adalah standar yang mengatur praktik akuntansi meliputi proses pembuatan, penyusunan, pencatatan dan penyajian data-data akuntansi khususnya di Indonesia. Standar akuntansi keuangan memiliki tujuan untuk menciptakan standar keseragaman bentuk laporan keuangan, sehingga mudah dipahami oleh seluruh pihak yang membutuhkan informasi akuntansi tersebut. Standar Akuntansi Keuangan disusun dan 
diterbitkan Dewan Standar Akuntansi Keuangan yang dibentuk oleh Ikatan Akuntansi Indonesia (IAI) untuk mengatur jalannya pelaksanaan bisnis dan memberikan panduan terkait tata cara penyusunan laporan keuangan suatu entitas bisnis di Indonesia (Cahyono, 2011). Standar Akuntansi Keuangan berisi beberapa pedoman, antara lain: 1) mengatur transaksi beserta pengungkapanya, 2) dalam standar pengungkapan yang berisi insiden transaksi, maupun segala informasi yang berkaitan dengan keuangan harus diungkap agar berguna dan tidak menyesatkan para pengguna laporan keuangan (Badria \& Diana, 2018).

\subsection{Standar Akuntansi Keuangan Entitas Mikro dan Menengah (SAK EMKM)}

Perkembangan teori akuntansi berdampak pada perkembangan standar-standar akuntansi yang berlaku di Indonesia. Saat ini, terdapat standar pelaporan keuangan khusus UKM atau UMKM yang disebut Standar Akuntansi Keuangan Entitas Mikro Kecil Menengah (SAK EMKM). EMKM adalah entitas tanpa akuntabilitas publik yang signifikan sebagaimana terdapat dalam Standar Akuntansi Keuangan Entitas tanpa Akuntabilitas Publik (SAK ETAP). SAK EMKM diterbitkan oleh dewan IAI dengan tujuan untuk mengedukasi dan memberikan pedoman kepada pelaku usaha UMKM terkait tata cara pembuatan laporan keuangan secara lengkap, detail, dan komprehensif. Secara umum fungsi disusunnya laporan keuangan bagi UMKM adalah untuk menjamin ketersediaan data terkait kinerja, laporan posisi keuangan serta perubahan posisi keuangan perusahaan. Ketersediaan data memudahkan pelaku usaha UMKM dan stakeholder untuk memperoleh informasi yang berguna untuk pembuatan keputusan (Dewi \& Sari, 2019; Djoko, 2015). Laporan keuangan UMKM menurut SAK EMKM dibuat berdasarkan asumsi dasar akrual dan terdiri dari tiga jenis laporan keuangan antara lain laporan posisi keuangan, laporan laba rugi, dan Catatan Atas Laporan Keuangan (CALK).

\subsection{Usaha Mikro Kecil dan Menengah (UMKM)}

Istilah yang sering diartikan UMKM berarti sebuah kegiatan ekonomi merujuk pada usaha pemilik perorangan atau kelompok yang di atur pada Undang-Undang Nomor 20 Tahun 2008 yang isinya mengatur beberapa kategori dari jumlah aset omset. Dijelaskan dalam UU No.9 Tahun 1995 pasal satu bahwa: "Usaha kecil adalah kegiatan ekonomi rakyat yang berskala kecil dan memenuhi kriteria kekayaan bersih atau hasil penjualan tahunan serta kepemilikan sebagaimana diatur dalam Undang - undang ini”. Menurut Undang-Undang Nomor 20 Tahun 2008, usaha mikro adalah usaha yang memiliki kekayaan bersih mencapai Rp 50.000.000,- tidak termasuk bangunan dan tanah tempat usaha dengan hasil penjualan setiap tahunnya paling banyak Rp 300.000.000.-. sedangkan usaha kecil adalah usaha yang memiliki kekayaan bersih Rp 50.000.000.- sampai maksimal Rp 500.000.000.- dengan hasil penjualan setiap tahunnya antara Rp 300.000.000.- sampai Rp 2.500.000.000.-.

\subsection{Persepsi UMKM}

Persepsi adalah proses kognitif yang dialami oleh seseorang dalam memahami informasi tentang lingkungannya. Proses ini melalui penglihatan, pendengaran, penghayatan, perasaan, dan penciuman yang digunakan untuk menafsirkan situasi. Secara mendasar makna persepsi digambarkan sebagai suatu penglihatan seseorang dalam menggambarkan sebuah sasaran yang berarti pandangan, pengertian dan anggapan, yang dimaksud adalah 
persepsi para pelaku UMKM (Kusuma \& Lutfiany, 2018). Persepsi para pelaku UMKM memainkan peran penting dalam penetapan tujuan suatu usaha UMKM, namun sasaran yang telah ditetapkan dapat berbeda dari realita sebenarnya (Setyawati \& Hermawan, 2018; Weber \& Geneste, 2014).

\subsection{Tingkat Kesiapan UMKM}

UMKM dalam mengaplikasikan SAK dapat dilihat sejauh mana pemahaman owner terhadap SAK apakah owner melakukan pembukuan secara rutin, memasang software akuntansi dan pembukuan pedoman akuntansi (Rahmawati \& Puspasari, 2017). Kesiapan UMKM dalam pengaplikasian perubahan SAK EMKM, dapat diketahui jika kesiapan UMKM sudah membuat pembukuan dari pedoman yang sudah diterapkan. Apakah sumber daya manusia dari UMKM ini sudah mengaplikasikan pembukuan menggunakan software akuntansi saat menginput data (Budiarto et al., 2018; Lestari, 2018). Jika para pelaku UMKM sama sekali tidak mengetahui tentang SAK EMKM serta tidak mencatat secara rutin pembukuan, SDM kurang memadai, maka bisnisnya dinilai belum siap mengaplikasikan SAK EMKM (Dewi \& Sari, 2019).

\subsection{Pengembangan Hipotesis}

Sistem pencatatan akuntansi merupakan proses pencatatan dan penyajian informasi terkait kondisi keuangan yang digunakan untuk membuat keputusan. Sistem pencatatan akuntansi yang diterapkan oleh tiap-tiap usaha dapat berbeda tergantung dari ukuran usaha tersebut, sehingga semakin besar ukuran usaha akan semakin kompleks sistem pencatatan akuntansi yang diperlukan. UMKM dengan control sistem akuntansi yang professional akan memperoleh nilai yang baik dari pemangku kepentingan (Andriani et al., 2014). SAK EMKM memuat tentang standar akuntansi yang memberikan keuntungan bagi pemilik usaha UMKM dan lebih sederhana dibandingkan dengan SAK ETAP (Nuvitasari et al., 2019). Tingkat penerapan pencatatan akuntansi berpengaruh signifikan pada SAK EMKM, dengan menerapkan standar yang sudah ditetapkan akan menambah kepercayaan pada akses modal perbankan atau lembaga bank lainnya (Pardita, 2019). Berdasarkan uraian tersebut, maka hipotesis yang dirumuskan adalah sebagai berikut:

\section{$H_{1}$ : Penerapan sistem pencatatan akuntansi berpengaruh terhadap penerapan SAK EMKM}

Pemahaman akuntansi merupakan persepsi yang dipandang sebagai fakta, kebenaran, atau informasi terkait proses pencatatan, penggolongan mengihktisaran kejadian-kejadian ekonomi yang disusun secara logis dan teratur (Setyawati \& Hermawan, 2018). Pemahaman akuntansi sangat diperlukan oleh Usaha Mikro Kecil dan Menengah (UMKM) karena penerapan akuntansi akan mengubah posisi keuangan menjadi informasi penting seperti untuk pengambilan investasi akan kredit pada bisnis usaha (Harryoga, 2015; Mulyadi \& Rozak, 2019). Tingkat pemahaman UMKM terkait standar akuntansi karena tingkat kebutuhan pihak eksternal memberikan dorongan pada seberapa paham dalam pemahaman, sehingga berhubungan positif dengan pencatatan akuntansi (Dang-duc, 2011). Beberapa pelaku UMKM menganggap informasi akuntansi itu tidak penting (Suparti \& Restuningdiah, 2018). Tingginya kemampuan owner dalam pemahaman akuntansi bisa 
menghasilkan hal baik yaitu berupa kualitas laporan keuangan (Tjun et al., 2009). Para pengusaha UMKM dengan persepsi kemudahan penggunaan yang semakin baik akan mengakibatkan kesiapan UMKM dalam menerapakan SAK EMKM juga semakin baik (Trisomantagani et al., 2017). Berdasarkan uraian tersebut, maka hipotesis yang dirumuskan adalah sebagai berikut:

\section{$\mathrm{H}_{2}$ : $\quad$ Tingkat pemahaman akuntansi berpengaruh terhadap penerapan SAK EMKM}

Secara mendasar makna persepsi digambarkan sebagai suatu penglihatan sesorang dalam menggambarkan sebuah sasaran yang berarti pandangan, pengertian dan anggapan pelaku UMKM (Kusuma \& Lutfiany, 2018). Persepsi para pelaku UMKM memainkan peran penting dalam penetapan tujuan suatu usaha UMKM, namun perbedaan antara sasaran dan realita akan selalu ada (Setyawati \& Hermawan, 2018; Weber \& Geneste, 2014). Tingkah laku dan penyesuaian ditentukan oleh persepsinya, hakikat dari persepsi merupakan penilaian seseorang terhadap objek tertentu (Hidayah, 2019). Tingkat pendidikan, pemanfaatan TI, dan lamanya usaha tidak berpengaruh terhadap pentingnya laporan keuangan berbasis SAK EMKM (Silvia \& Azmi, 2019). Pengusaha bisa belajar dalam penyesuaian diri di lingkungan tertentu dengan adanya penambahan sosialisasi yang berpengaruh signifikan terhadap SAK EMKM (Janros, 2018). Persepsi pemahaman pengusaha UMKM berpengaruh terhadap penggunaan SAK EMKM, awalnya pemilik usaha beranggapan dalam menyusun laporan keuangan sulit dilakukan, dengan terbitnya SAK EMKM menjadi mudah dipelajari (Badria \& Diana, 2018; Nurfadilah et al., 2019). Berdasarkan uraian tersebut, maka hipotesis yang dirumuskan adalah sebagai berikut:

\section{H3: Persepsi UMKM berpengaruh terhadap penerapan SAK EMKM}

Kesiapan UMKM dalam pengaplikasian perubahan SAK EMKM, dapat diketahui melalui pembukuan yang dilakukan secara rutin oleh owner, jika para pelaku UMKM sama sekali tidak mengetahui tentang SAK EMKM serta tidak mencatat secara rutin pembukuan maka bisnisnya dinilai belum siap (Dewi \& Sari, 2019). Kesiapan merupakan suatu kondisi seorang pelaku usaha bisa menghadapi siklus perubahan pencatatan keuangan yang di dalamnya mengaplikasikan SAK EMKM (Achjari et al., 2011). Pemilik UMKM mempunyai pandangan bahwa pengaplikasian SAK EMKM hanya membuang biaya dan waktu (Darcy et al., 2014). Tingkat kesiapan usaha akan menghasilkan pemahaman yang cukup baik terhadap penerapan SAK ETAP (Yuliza \& Yunawati, 2015). Kesiapan para pelaku UMKM sudah cukup tinggi dalam menyusun laporan keuangan atas usaha yang dijalankan sesuai SAK EMKM yang telah ditetapkan (Dewi \& Sari, 2019). Berdasarkan uraian tersebut, maka hipotesis yang dirumuskan adalah sebagai berikut:

\section{H4: Tingkat kesiapan pelaku UMKM berpengaruh terhadap penerapan SAK EMKM}

\section{Metode Penelitian}

Penelitian ini dilaksanakan pada tahun 2020. Populasi penelitian meliputi UMKM yang berdomisili di Yogyakarta, usaha kepemilikan tunggal, dan UMKM yang menggunakan SAK EMKM. Penelitian ini memperoleh responden sebanyak 72 pemilik UMKM yang berada di Yogyakarta yang meliputi kabupaten: Bantul, Sleman, Gunungkidul, Kulon Progo dan Kota Yogyakarta. Metode pemilihan sampel menggunakan purposive sampling yang 
mengambil kriteria pada DK04. ED SAK EMKM sebagaimana diregulasi UU No. 20 Tahun 2008. Sumber data yang digunakan dalam penelitian ini adalah data primer dengan menggunakan kuesioner.

\subsection{Definisi Operasional Variabel}

Penelitian ini menggunakan variabel independen penerapan sistem pencatatan akuntansi, pengetahuan akuntansi, pemahaman akuntansi, persepsi pemilik dan kesiapan pelaku UMKM. Variabel dependen pada penelitian ini adalah penerapan SAK EMKM. Indikator yang digunakan pada penelitian ini ditunjukkan pada tabel 1.

Tabel 1. Instrumen Penelitian

\begin{tabular}{|c|c|}
\hline Variabel & Instrumen \\
\hline $\begin{array}{l}\text { Penerapan Sistem Pencatatan } \\
\text { Akuntansi (Sholikin \& Setiawan, } \\
\text { 2018) }\end{array}$ & $\begin{array}{l}\text { 1. Penyusunan pencatatan berbasis akrual yang menjadikan dasar } \\
\text { pengimplementasikan SAK EMKM }\end{array}$ \\
\hline $\begin{array}{l}\text { Pemahaman akuntansi (Yanti, } \\
\text { 2019) }\end{array}$ & $\begin{array}{llll}\text { 1. Diperlukan dalam menyusun laporan keuangan belum } \\
\text { diterapkan secara optimal } & & \\
\text { 2. Adanya pengetahuan akuntansi } & & \\
\text { 3. Handal menyusun rinci pelaporan keuangan } & & \\
\end{array}$ \\
\hline $\begin{array}{l}\text { Persepsi pelaku UMKM (Badria \& } \\
\text { Diana, 2018) }\end{array}$ & $\begin{array}{l}\text { 1. Mengerti jalannya perkembangan bisnis } \\
\text { 2. Mendorong laju kepentingan usahanya } \\
\text { 3. Pengelolaan usaha yang baik } \\
\text { 4. Mudah dalam melakukan kontrol keuangan } \\
\text { 5. Mudah dipahami } \\
\text { 6. Evaluasi } \\
\text { 7. Penyajian informasi akuntansi yang gagal } \\
\text { 8. Pandangan kondisi usaha yang jelas } \\
\text { 9. Memudahkan dalam pengambilan keputusan } \\
\text { 10. Jaminan penyaluran kredit bank }\end{array}$ \\
\hline $\begin{array}{l}\text { Kesiapan pelaku UMKM (Lestari, } \\
\text { 2018) }\end{array}$ & $\begin{array}{l}\text { 1. Seberapa jauh pemahaman UMKM terhadap SAK } \\
\text { 2. Sudahkah berpedoman pada SAK } \\
\text { 3. Ada pegawai khusus dalam pelaporan keuangan }\end{array}$ \\
\hline $\begin{array}{l}\text { Penerapan SAK EMKM (Sholikin } \\
\text { \& Setiawan, 2018) }\end{array}$ & $\begin{array}{l}\text { 1. } \text { Kriteria penerbitan SAK EMKM } \\
\text { 2. Sistem pencatatan SAK EMKM } \\
\text { 3. } \\
\text { Ketersediaan SDM }\end{array}$ \\
\hline
\end{tabular}

\section{Hasil Dan Pembahasan}

Peneliti melangsungkan pengumpulan data selama 2 bulan dengan mengaplikasikan metode online dan offline. Pada bulan pertaman peneliti dapat memperoleh 19 responden dan puncaknya terjadi pada bulan kedua, pada tabel 1 mengenai deskripsi data lengkap responden, tabel 2 memperlihatkan hasil uji validitas yang diukur dengan pearson correlation, tabel 3 memperlihatkan uji realibilitas variabel menggunakan nilai cronbach's alpha.

Hasil pengujian hipotesis pertama menunjukan bahwa penerapan pencatatan sistem akuntansi tidak berpengaruh signifikan terhadap SAK EMKM. Oleh karena itu, dapat disimpulkan bahwa pencatatan akuntansi belum memotivasi pemilik UMKM untuk menerapkan SAK EMKM. Hal ini disebabkan para pengusaha belum menerapkan sistem pencatatan akuntansi. Pengusaha berpendapat bahwa penghasilan yang tidak menentu menjadi alasan untuk tidak menerapkan sistem pencatatan yang rinci. Metode pencatatan 
akuntansi pada beberapa sampel terutama di usaha kuliner menunjukkan bahwa para pelaku menggunakan pembukuan sederhana walaupun pemilik usaha sudah mengerti pentingnya standar pencatatan akuntansi. Para pelaku usaha yang masih menggunakan pembukuan sederhana meskipun telah mengetahui pentingnya standar pencatatan akuntansi menyebabkan penurunan motivasi untuk menerapkan SAK EMKM. Hasil penelitian ini mendukung penelitian Barus et al. (2018) yang mengungkapkan bahwa pelaku usaha sering mencampurkan hasil penjualan dan uang pribadi. Pembelian dan pengeluaran dilakukan dengan pencatatan yang isinya hanya penjualan, pendapatan dan pengeluaran yang mengakibatkan terjadi kesulitan dalam mengontrol laba bersih (Savitri \& Siafudin, 2018). Oleh sebab itu, Bank tidak terlalu tertarik dalam penyaluran modal UMKM karena keterbatasan laporan keuangan UMKM (Silvia \& Azmi, 2019).

Tabel 2: Karakteristik Responden

\begin{tabular}{|c|c|c|c|c|c|c|c|}
\hline \multicolumn{8}{|c|}{ Lokasi Usaha } \\
\hline & & $\begin{array}{c}\text { Kota } \\
\text { Yogyakarta }\end{array}$ & Bantul & Sleman & $\begin{array}{c}\text { Gunung } \\
\text { kidul }\end{array}$ & $\begin{array}{l}\text { Kulon } \\
\text { Progo }\end{array}$ & Total \\
\hline \multirow[t]{9}{*}{ Jenis Usaha } & Usaha Kuliner & 8 & 4 & 4 & 3 & 3 & 22 \\
\hline & Usaha Furniture & - & 1 & 1 & - & 2 & 4 \\
\hline & Usaha & 3 & 4 & 2 & 1 & 2 & 12 \\
\hline & Warung/Toko & & & & & & \\
\hline & Usaha Fashion & 3 & 3 & 3 & 1 & - & 10 \\
\hline & Usaha Kosmetik & 1 & 2 & 2 & - & - & 5 \\
\hline & Usaha & - & - & - & 2 & - & 2 \\
\hline & Peternakan & & & & & & \\
\hline & Lain-lain & 4 & 4 & 3 & 1 & 2 & 14 \\
\hline Total & & 19 & 20 & 16 & 8 & 9 & 72 \\
\hline \multirow[t]{6}{*}{ Pendidikan } & SD & 1 & - & - & - & - & 1 \\
\hline & SMP & & & & & & 0 \\
\hline & SMA & 11 & 18 & 13 & 7 & 7 & 56 \\
\hline & Diploma & 3 & - & - & - & - & 3 \\
\hline & $\mathrm{S} 1$ & 4 & 2 & 3 & 1 & 2 & 12 \\
\hline & $\mathrm{S} 2$ & - & - & - & - & - & 0 \\
\hline Total & & 19 & 20 & 16 & 8 & 9 & 72 \\
\hline \multirow[t]{2}{*}{ Jenis Kelamin } & Laki-laki & 13 & 5 & 6 & 2 & 2 & 28 \\
\hline & Perempuan & 6 & 15 & 10 & 6 & 7 & 44 \\
\hline Total & & 19 & 20 & 16 & 8 & 9 & 72 \\
\hline
\end{tabular}

Tabel 3: Hasil Uji Reliabilitas

\begin{tabular}{lcc}
\hline \multicolumn{1}{c}{ Variabel } & Cronbach's alpha & Keterangan \\
\hline Penerapan Sistem Pencatatan (PSP) & 0,889 & Reliabel \\
Pemahaman Akuntansi (PA) & 0,836 & Reliabel \\
Persepsi Usaha (PU) & 0,923 & Reliabel \\
Kesiapan UMKM (KU) & 0,856 & Reliabel \\
Penerapan SAK EMKM (PSE) & 0,933 & Reliabel \\
\hline
\end{tabular}

Hasil pengujian hipotesis kedua menunjukan bahwa pemahaman akuntansi tidak berpengaruh signifikan terhadap penerapan SAK ETAP. Hal ini disebabkan kurangnya kompetensi yang dimiliki SDM di bidang keuangan (Putri et al., 2015). SDM yang kurang berkompeten di bidang keuangan disebabkan oleh faktor pendidikan, pelatihan, pengalaman dan serta pengetahuan yang masih sedikit. SDM yang kurang berkompeten di bidang 
keuangan berdampak pada rendahnya pemahaman akuntansi. Mayoritas sampel penelitian ini memiliki latar belakang pendidikan SMA dengan jumlah 56 dari 72 sampel pemilik UMKM 77,78\% dengan pendidikan SMA. Background pendidikan menjadikan sebuah patokan pemilik usaha dalam menerapkan keputusan yang baik bagi jalan usahanya, sebab itu latar belakang pendidikan menjadi garis besar dalam menjalankan bisnis (Susfayetti et al., 2018).

Tabel 4: Hasil Uji Regresi Linear Berganda

\begin{tabular}{llll}
\hline \multicolumn{1}{c}{ Variabel } & B & P value & \multicolumn{1}{c}{ Hasil } \\
\hline Penerapan Sistem Pencatatan & $-0,111$ & 0,120 & H1 Tidak didukung \\
Pemahaman Akuntansi & $-0,029$ & 0,767 & H2 Tidak didukung \\
Persepsi Usaha & 0,282 & $0,014 *$ & H3 Didukung \\
Kesiapan UMKM & 0,498 & $0,000^{* *}$ & H4 Didukung \\
\hline F Hitung: 16,892 & & $0,000^{* *}$ & \\
Adjusted $\mathrm{R}$ Square: 0,487 & & & \\
** Sig $<1 \%, *$ sig $<5 \%$ & & &
\end{tabular}

Hasil pengujian hipotesis ketiga menunjukan bahwa persepsi UMKM berpengaruh positif dan signifikan terhadap penerapan SAK EMKM. Oleh karena itu, dapat disimpulkan bahwa persepsi pengusaha UMKM akan meningkatkan motivasi pelaku usaha untuk menerapkan SAK EMKM. Hasil penelitian ini selaras dengan penelitian Kusuma \& Lutfiany (2018). Persepsi UMKM yang baik akan meningkatkan keinginan untuk menerapkan tata cara penyusunan laporan keuangan sesuai SAK EMKM yang dapat memberikan dampak positif terhadap usaha yang dimiliki. Persepsi usaha dapat diartikan sudut pandang pemilik bisnis pada objek peristiwa mengenai perkembangan, kepentingan dan penigkatan dalam business (Badria \& Diana, 2018; Salmiah et al., 2019). Persepsi usaha UMKM bisa merubah mindset pemilik usaha sehingga dalam penerapan penyusunan pelaporan keuangan sesuai SAK EMKM itu sesuatu hal yang mudah di kerjakan (Nurfadilah et al., 2019).

Hasil pengujian hipotesis keempat menunjukan bahwa kesiapan pelaku UMKM memiliki pengaruh positif dan signifikan terhadap penerapan SAK EMKM. Oleh karena itu, dapat disimpulkan bahwa pelaku UMKM yang memiliki kesiapan baik akan mampu menyesuaikan dengan regulasi yang ada termasuk penerapan SAK EMKM (Pardita 2019). Kesiapan pelaku UMKM merupakan kondisi dimana pelaku usaha mampu menjawab tantangan dan melakukan penyesuaian terhadap perubahan aturan khususnya penerapan standar SAK EMKM. Tingkat kesiapan UMKM dapat dilihat melalui kondisi nyata UMKM tersebut (Lestari, 2018). UMKM yang memiliki tingkat kesiapan baik mampu menerapkan pencatatan sesuai aturan SAK EMKM yang berlaku.

\section{Simpulan dan Saran}

Berdasarkan penelitian ini, bisa ditarik kesimpulan bahwa hipotesis pencatatan sistem akuntansi dan pemahaman akuntansi di Wilayah Daerah Istimewa Yogyakarta tidak dapat membuktikan berpengaruh signifikan terhadap penerapan SAK EMKM. Hasil pengujian hipotesis persepsi usaha dan kesiapan UMKM dapat menunjukan bahwa terdapat pengaruh terhadap implementasi SAK EMKM. Penelitian ini memiliki keterbatasan pertama, hanya pada lingkup usaha kecil menengah yang ada di Daerah Istimewa Yogyakarta, sehingga 
sampel tidak bisa digeneralisasi (Pramudiati et al., 2019). Saran untuk research mendatang bisa mengambil sempel UMKM yang besar sebagai responden sehingga analisis yang dilakukan bisa terjadi banyak kemungkinan. Kedua, penelitian ini tidak menguji latar pendidikan dan tingkat pendidikan owner, saran untuk research selanjutnya bisa menambahkan variabel tingkat pendidikan owner yang berhubungan sangat erat dengan pemahaman akuntansi (Meidiyustiani, 2016). Ketiga penelitian ini menggunakan metode kuisioner sehingga jawaban yang diberikan tidak sesuai dengan keadaan aslinya, saran untuk penelitian mendatang bisa mengimbuhi interviuw dan obvervasi yang bisa menjadikan tingkat data lebih akurat dari responden (Janros, 2018; Whetyningtyas, 2015).

\section{Daftar Pustaka}

Achjari, D., Abdillah, W., Suryaningsum, S., \& Suratman. (2011). Kesiapan usaha mikro, kecil dan menengah industri kreatif untuk mengadopsi teknologi informasi. Jurnal Akuntansi dan Auditing Indonesia, 15(2), 143-160.

AL-Shboul, M. A. (2018). Towards better understanding of determinants logistical factors in SMEs for cloud ERP adoption in developing economies. Business Process Management Journal, 25(5), 887-907. https://doi.org/10.1108/BPMJ-01-2018-0004

Andriani, L., Atmadja, A. T., \& Sinarwati, N. K. (2014). Analisis penerapan pencatatan keuangan berbasis SAK ETAP pada usaha kecil, menegah (UMKM) (Sebuah studi intrepetatif pada Peggy Salon). Juranl Akuntansi, Ekonomi dan Manajemen, 2(1), 112.

Anisykurlillah, I., \& Rezqika, B. (2019). Faktor yang mempengaruhi implementasi SAK ETAP pada UMKM dengan ketidakpastian lingkungan sebagai variabel moderasi. Jurnal Akuntansi dan Keuangan Indonesia, 5(4), 18-35.

Badria, N., \& Diana, N. (2018). Persepsi pelaku UMK dan sosialisasi SAK EMKM terhadap diberlakukanya laporan keuangan yang berbasis SAK EMKM. Jurnal Ekonomi dan Keuangan, 18(1), 55-66.

Barus, I. N. E., Indrawati, A., \& Sholihin, D. (2018). Implementasi SAK EMKM (Entitas Mikro, Kecil dan Menegah) pada UMKM Borneo Food Truk Samarinda Community. Journal Accounting and Business Management, 2(2), 176-183.

Budiarto, D. S., \& Pramudiati, N. (2018). Does technology improve SMEs business success? Empirical research on Indonesian SMEs. Journal of Economics and Management Sciences, 1(2), 115-121. https://doi.org/https://doi.org/10.30560/jems.v1n2p115

Budiarto, D. S., Sari, M. W., Sudaryana, A., \& Prabowo, M. A. (2018). It implementation Indonesia SMEs: Challenge or barriers? International Jurnal of Business and Society, 19(117), 546-553.

Cahyono, A. T. (2011). Meta teori standar akuntansi keuangan di Indonesia - menuju konvergensi SAK di masa globalisasi. Eksis Riset, 7(2), 1884-1897.

Dang-duc, S. (2011). Compliance with accounting standards by SMEs in transitional economies: Evidence from Vietnam. Journal of Applied Accounting Research, 12(2), 96-107,. https://doi.org/https://doi.org/10.1108/09675421111160673

Darcy, C., Hill, J., McCabe, T., \& McGovern, P. (2014). A consideration of organisational sustainability in the SME context. European Journal of Training and Development, $38(5), 398-414$.

Dewi, L. G. K., \& Sari, L. G. J. (2019). Analisis kesiapan dan pengetahuan dalam penyusunan laporan keuangan berbasis standar akuntansi keuangan EMKM. Jurnal Ilmiah Akuntansi, 4(2), 141-160. 
Divianto., \& Febrianty. (2017). Pengaruh pemahaman pelaku UKM dalam menyusun UKM sebagai moderasi variabel. International Journal of Social Science and Busines, 1(3), $166-176$.

Djoko, S. G. (2015). Peranan laporan keuangan dalam rangka memberdayakan dan mengembangkan usaha mikro kecil dan menengah di Kabupaten Sukoharo. Jurnal Akuntansi dan Pajak, 16(1), 2015.

Harini, A. S., Kurniawan, A., \& Umiyati, I. (2019). The influence of accounting information system implementation and internal control effectiveness on the performance of employees (Case study on micro, small, medium enterprises subang regency). Journal of Accounting For Sustainable Society, 1(1), 88-107.

Harryoga, S. (2015). Faktor-faktor penentu tingkat pemahaman akuntansi. Jurnal Ekonomi dan Bisnis, 18(3), 75-90.

Hidayah, M. N. S. (2019). Persepsi pelaku UMKM terhadap laporan keuangan berdasarkan standar akuntansi keuangan entitas tanpa akuntabilitas publik (SAK ETAP). Jurnal Akuntansi Indonesia, 8(1), 39-55.

Ivers, A. M., Byrne, J., \& Byrne, P. J. (2016). Analysis of SME data readiness: A simulation perspective. Journal of Small Business and Enterprise Development, 23(1), 1-27. https://doi.org/http://dx.doi.org/10.1108/JSBED-03-2014-0046

Janros, V. S. E. (2018). Analisis persepsi pelaku UMKM dan sosialisasi SAK EMKM terhadap diberlakukannya laporan keuangan yang berbasis SAK EMKM. Jurnal Akuntansi dan Bisnis, 11(1), 97-105.

Kusuma, I. C., \& Lutfiany, V. (2018). SMEs perceptons in understanding the accounting stard for SMEs. Jurnal Akunida, 4(2), 1-14.

Lestari, E. P. (2018). Kesiapan UMKM dalam implementasi SAK EMKM pengrajin mebel Desa Catak Gayam, Mojowarno. Jurnal Riset Akuntansi dan Keuangan Dewantara, 2(1), 24-33.

Lestari, N. A., \& Rustiana, S. H. (2019). Pengaruh persepsi owner dan pengetahuan akuntansi dalam penggunaan sistem informasi akuntansi terhadap kinerja usaha mikro, kecil, dan menengah di Pemulang. Journal of Business \& Enterpreneurship, 1(1), 6780.

Lestari, S. L. (2019). Implementasi standar akuntansi keuangan entitas tanpa akuntabilitas publik dalam penyajian laporan keuangan pada PT Aurindo Jaya Perkasa. Jurnal Riset Keuangan, 1(1132), 70-83.

Masdupi, E., Rasyid, R., \& Rahmiati. (2019). Pengelolaan keuangan dan akses permodalan sebagai solusi dalam pengembangan usaha kecil sulaman di Sagari Panampuang Kabupaten Agam Sumatera Barat. JP-Ipteks, 1(1), 50-57.

Meidiyustiani, R. (2016). Pengaruh pemilik, pemahaman akuntansi dan motivasi pemilik terhadap penerapan standar akuntansi keuangan untuk entitas tanpa akuntabilitas publik (SAK ETAP). Journal of Accounting and Finance, 1(01), 13-27.

Mulyadi, A., \& Rozak, M. A. (2019). Pengaruh kompetensi dan profesionalisme dosen akuntansi terhadap tingkat pemahaman mahasiswa akuntansi. Journal of Accounting Science, 3(1), 1-17. https://doi.org/10.21070/jas.v3i1.2535

Nurfadilah, P., Diana, N., \& Mawardi, M. C. (2019). Pengaruh persepsi pengusaha mikro kecil menengah dan pemahaman terhadap penggunaan SAK EMKM. Jurnal Riset Akuntansi, 08(11), 116-128.

Nuvitasari, A., Citra, N., \& Martiana, N. (2019). Implementasi SAK EMKM sebagai dasar penyusunan laporan keuangan usaha mikro kecil dan menengah (UMKM). International Journal of Social Science and Busines, 3(3), 341-347.

Pardita. (2019). Pengaruh tingkat pencatatan penerapan sistem pencatatan akuntansi, tingkat 
pemahaman akuntansi dan tingkat kesiapan pelaku UMKM terhadap SAK EMKM pada UMKM di Kabuoaten Gianyar. Jurnal Ilmiah Akuntansi dan Humanika, 9(3), 202-212.

Pramudiati, N., Putri, A. Z., \& Basri, A. I. (2019). Penerapan SAK ETAP, Kinerja Usaha, dan Keberlanjutan UMKM di Provinsi Daerah Istimewa Yogyakarta. Jurnal Akuntansi Dewantara, 3(2), 149-155. https://doi.org/10.26460/AD.V3I2.5190

Purwanti, E. (2012). Pengaruh Karakteristik wirausaha, modal, strategi pemasaran terhadap perkembangan UMKM di desa Dayaan dan Kalilondo Salatiga. Jurnal Ilmiah Manajemen dan Akuntantansi, 5(9), 13-28.

Puspita, M. E., \& Promono, J. (2019). Factors affecting the use of accounting information in small and medium enterprises (SMEs): A study on SMEs in Tingkir, Salatiga. The Indonesian Accounting, 9(2), 207-225.

Putri, N. K. R., Darmawan, N. A. S., \& Werastuti, D. N. S. (2015). Akuntansi dan sistem pengendalian internal terhadap kualitas laporan keuangan (Studi pada Koperasi Simpan Pinjam di Kecamatan Buleleng). Jurnal UNDIKSA, 3(1), 1-11.

Rahmawati, T., \& Puspasari, O. R. (2017). Implementasi SAK ETAP dan kualitas laporan keuangan UMKM terkait akses modal perbankan. Jurnal Kajian Akuntansi, 1(1), 4962.

Ramdani, M. R., Kamidin, M., \& Ajmal, A. (2018). Implementasi SAK-ETAP pada UMKM warkop di Kota Makassar. Jurnal RAK (Riset Akuntansi Keuangan), 3(2), 1-19.

Salmiah, N., Nanda, S. T. R. I., \& Adino, I. (2019). Faktor-faktor yang mempengaruhi penyusunan laporan keuangan sesuai SAK EMKM: Survey pada UMKM yang terdaftar di Dinas Koperasi dan UKM Kota Pekanbaru. Jurnal Akuntansi dan Kompetif, 3(1), 34-42.

Savitri, R. V., \& Siafudin. (2018). Pencatatan akuntansi pada usaha mikro kecil dan menengah (Studi UMKM Mr. Pelangi Semarang). Jurnal Manajemen Bisnis dan Inovasi, 5(2), 117-125.

Setyawati, Y., \& Hermawan, S. (2018). Persepsi pemilik dan pengetahuan akuntansi pelaku usaha mikro kecil dan menengah (UMKM) atas penyusunan laporan keuangan. Riset Akuntansi dan Keuangan Indonesia, 3(2), 161-204.

Sholikin, A., \& Setiawan, A. (2018). Kesiapan UMKM terhadap implementasi SAK EMKM (Studi UMKM Di Kabupaten Blora). Journal of Islamic Finance and Accounting, 1(2), $1-16$.

Silvia, B., \& Azmi, F. (2019). Analisis faktor-faktor yang mempengaruhi persepsi pengusaha UMKM terhadap laporan keuangan berbasis SAK EMKM. Jurnal Analisis Bisnis Ekonomi, 17(1), 57-73.

Suparti, A. C. D., \& Restuningdiah, N. (2018). The analysis of acounting system formulation based on SAK EMKM. Internasional Journal of Business, Economics and Law, 16(5), 229-234.

Supriadi, Y. N. (2018). Analisis keberlanjutan usaha UMKM di Propinsi Banten. Jurnal Akuntansi dan Manajemen, 7(1), 24-34.

Susfayetti, Afrizal, \& Safelia, N. (2018). Pengaruh pemahaman teknologi informasi, kualitas pendidikan, lama usaha dan ukuran usaha terhadap penerapan SAK ETAP pada ekonomi kreatif (Studi kasus pada UMKM di Kota Jambi). Jurnal Akuntansi Keuangan dan Bisnis, 1(2), 17-23.

Tjun, L. T., Setiawan, S., \& Setiana, S. (2009). Pengaruh kecerdasan emosional terhadap pemahaman akuntansi dilihat dari perspektif gender. Jurnal Akuntansi, 1(2), 101-118.

Trisomantagani, K. A., Yasa, I. N. P., \& Yuniarta, G. A. (2017). Persepsi usaha mikro, kecil dan menengah terhadap kesiapan dalam menerapkan SAK EMKM. Jurnal Akuntansi, 
1(2), 1-11.

Weber, P. C., \& Geneste, L. (2014). Exploring gender-related perceptions of SME success. International Journal of Gender and Entrepreneurship, 6(1), 15-17. https://doi.org/http://dx.doi.org/10.1108/IJGE-04-2013-0038

Whetyningtyas, A. (2015). Analisi pengaruh kemampuan menyusun laporan keuangan dan jiwa kewirausahaan terhadap kinerja operasional UMKM. Prosiding Seminar Nasional \& Call for Papers, 1(1), 57-68.

Wirjono, E. R., \& Raharjono, D. A. B. (2012). Survei pemahaman dan pemanfaatan informasi akuntansi dalam usaha kecil menengah di Daerah Istimewa Yogyakarta. Jurnal Ilmiah Akuntansi dan Bisnis, 7(1), 205-216.

Yanti, N. P. M. D. (2019). Pengaruh etika kepemimpinan dan tingkat pemahaman akuntansi terhadap kualitas pelaoran keuangan pada PT. Raditiya Dewata Perkasa. Akuntansi \& Manajemen, 1(2), 271-299.

Yenni, E. (2017). Pengaruh pemahaman akuntansi dan pengalaman kerja aparatur terhadap penyusunan laporan keuangan daerah para pemerintah Kota Banda Aceh. Indonesian Journal for the Economics, Management and Technology, 1(2), 91-96.

Yuliza, A., \& Yunawati, S. (2015). Analisis pemahaman terhadap penerapan SAK ETAP pada Bank Perkreditan Rakyat di Kota Pasir Pengaraian. Jurnal Ilmiah Cano Ekonomos, 4(1), 11-18.

Yusup, J. (2017). Analisis perumusan dan penerapan sistem akuntansi pada usaha kecil menengah (Studi kasus UMKM bakso Pejangan). Jurnal Ilmiah Indonesia, 2(11), 7690 . 